\title{
Radical investment in the curriculum in times of Covid-19: Can we question the anti-science discourses?
}

\author{
Alice Casimiro Lopes ${ }^{1} \mathbb{D}$
}

Accepted: 19 January 2021 / Published online: 18 May 2021

(C) UNESCO IBE 2021

\begin{abstract}
This article questions the centrality of knowledge and learning in the curriculum, as well as the restriction of education to learning even when education is thought of as consisting of ways to combat anti-science discourses in the name of combating Covid19. Based on discourse theory and deconstruction, with a focus on the notions of radical investment, contextualization, interpretation, and fantasy, the article reaffirms a post-foundational notion of curriculum theory and defends the possibility that curriculum and school can be spaces of affective relationships, bonds, and subjectivities willing to invest in life and thereby contribute to fighting the current pandemic.
\end{abstract}

Keywords Contextualization · Covid-19 - Curriculum · Discourse $\cdot$ Knowledge · Pandemic $\cdot$ School $\cdot$ Subjectivation

Contingency would be abolished. It was the dream of the perfect death, the Socratic death, the philosophical death: absolute self-coincidence at the point of disappearance. Autarchy. Autonomy.

Authenticity. Autism. It was a delusion of control.

(Simon Critchley 2014)

There is a tradition that expands the notion of curriculum beyond the course of study and incorporates an autobiographical way to study the lived experience, as in the notion of currere (Pinar 1975, 2004). This tradition also values notions such as learning experiences and the production of subjectivities and culture throughout life and/or in different spaces and times. (See, for example, Kriedel 2010.) In certain contexts, the relationship between curriculum and school is considered almost a truism, justified by the historical link between curriculum theory and mass schooling. However, I understand that the

Alice Casimiro Lopes

alicecasimirolopes@gmail.com

1 State University of Rio de Janeiro, Bloco C - R. São Francisco Xavier, 524 - Maracanã,

Rio de Janeiro, RJ 20943-000, Brazil 
identification between curriculum and school, considering school as a place or a building, needs problematization.

This way of conceiving the curriculum-school relationship is often superimposed over the restriction of education to learning. If the meanings of education are limited to the transmission of contents related to school subjects and to the fulfillment of instructional objectives, then school is a specific place where learning occurs through the curriculum.

At this moment, when we are experiencing a pandemic that forces us to avoid agglomerations and physical contact and makes us stand at least three meters apart from each other, the school building, as a place for curriculum development, becomes an impossibility. Even though social isolation throughout the world has been only partially fulfilled, with serious political conflicts among federal and state governments, economic groups, and the wider population in relation to health policy and the pandemic, for the time being, there is a reasonable consensus that schools and universities must remain without face-to-face activities.

Some feel we should wait for the greatest risks of the pandemic to pass so that we can return to school as we know it, while others use this moment to expand on what they already have done before: questioning the school institution by favoring distance education, online activities, and home schooling. Sometimes, these actions are associated with the defense of instrumental curriculum proposals (even conservative proposals), aiming at profit and the withdrawal of education from the hands of teachers and educational managers.

The rise of online learning was predicted before the pandemic. As reported in Forbes (Koksal 2020), the online education market will be valued at $\$ 350$ billion by 2025 . These numbers will certainly rise with the prospect of "hybrid education" (online and face-toface simultaneously). The third sector is also being mobilized to produce materials and tools to support managers, teachers, and families in remote learning.

Identifying this initiative is nothing new. Institutions long active in political networks in support of school practices and even in the production of curricular proposals and training materials for teachers and students under the logic of philanthropy (Ball 2012) have spread rapidly through websites and YouTube channels. It is possible to draw an analogy with another movement that already exists that has expanded with the pandemic: the company customer vision, which proclaims, "There is nothing more important than our customers". This movement organizes consumers on social networks into communities that support the products they are interested in and gets emotionally involved in selling to them. The pandemic has thus become an excellent opportunity to test proposals for expanding online consumption, whether what is being consumed is a tangible object, a desire, or an educational product like a curriculum proposal.

In this article, I try to distance myself from those who regard online teaching as inexorable and assert that online teaching materials will effectively replace schools and teachers as we know them. I also try to distance myself from those who take a stand against any online activity, who just say "no" to these processes to defend school as we know it. I am not interested in online learning or teaching, as I am not interested in face-to-face learning or teaching. I am interested in the educational possibilities of interactions among teachers and students through the curriculum, wherever these subjects are, online or in person.

Due to this interest, my intention is to investigate the discourses that intersect in those moments of questioning school and curriculum. I seek to understand how criticisms of school and curriculum and criticisms of science and knowledge have arisen out of the pandemic and favor investments in online teaching (e-learning). I intend to argue that to problematize such criticisms in turn implies a radical investment, a different kind 
of investment-not an economic one-in the curriculum and not a defense of school knowledge as the center of the curriculum.

Although I start from my understanding of this issue in Brazil, I try to place it in the international context of expanding conservatism and post-truth. In Brazil, actions in defense of e-learning take place in a context in which schools, as places where education and curriculum are developed, also suffer attacks from conservative and reactionary movements that conceive such spaces as disseminators of ideologies and values linked to left-wing ideas considered contrary to the family principles and the Brazilian society. As discussed elsewhere (Lopes 2019), the "soldiers" in a cultural war in defense of the Homeland, the family, and the values of religion act against an ideology unified by the denomination "cultural Marxism". To this "army", cultural Marxism encompasses neo-Marxists, strict Marxists, those who defend the Frankfurt School, Paulo Freire's supporters, post-structuralists, deconstructionists, and all defenders of multiculturalism who are active in changing the cultural and educational ground of the country and who are considered capable of destroying capitalist Western civilization (that is, of course, white, male, and heterosexual "civilization").

This process has been linked to criticism of and global disregard for scientific conclusions (Schwartzburg 2019) through a chain of substitution of signifiers by which the phrases "cultural Marxism", "human and social sciences", "science", and "university" are made equivalent, guaranteeing antagonism to the public university institution (Lopes 2019). This process did not begin with the Covid-19 pandemic but is expanding at this moment as the country's political-cultural dispute contaminates actions in the health sector by repudiating scientific theories.

The Brazilian situation may seem to many a unique perspective in relation to curriculum policy. However, it is related to the international movements I wish to analyze. For example, the Brazilian pandemic scenario is similar to that of the United States with respect to Donald Trump and his notion of alternative facts. Jair Bolsonaro in Brazil and Trump in the US have both relied on an anti-science discourse or defend an "alternative science" (contrary to supposedly left-wing scientific principles). Followers of conservative and reactionary governments, with their robots for mass dissemination of WhatsApp messages and Twitter posts, disseminate contradictory or even false data, the famous "fake news", whose publications downplay the seriousness of the disease caused by the coronavirus or use a single isolated case as evidence for such positions as: "Chloroquine is a drug that can save everyone", "Social isolation does not reduce contagion", "There are not so many deaths, the numbers are invented, and empty coffins are buried", "China created the virus in a laboratory to take over the world", "The Chinese vaccine is not to be trusted". It is also possible to relate this situation to the growing anti-vaccine movement. As highlighted in a recent article in The Lancet (Burki 2020), 31 million people follow anti-vaccine groups on Facebook, with 17 million subscribing to similar accounts on YouTube.

Further studies are needed of the phenomenon of "fake news". The common assertion that "if it is news, it shouldn't be fake" projects an assumption of factual truth, of fake "versus" true news referenced in an ideal climate of press neutrality. Without aiming to trivialize a phenomenon that transcends the usual limits of journalism committed to certain political views, I believe that fake news requires an analysis of how it leads us to consider power relations in the production of truth in politics. Farkas and Schou (2018, p. 300) begin this discussion by stating that "'fake news' has gradually become a floating signifier used within different discourses to criticize, delegitimize and exclude opposing political projects". 
Findings like this tend to raise questions about school. There are those who consider school education insufficient to prevent such conceptions, opening the door to materials and proposals prepared outside of school. On the other hand, there are those who want the school curriculum centered on knowledge in order to prevent the advancement of what has been called post-truth. I am in agreement with Farkas and Schou (2018) that it is more important to understand how the post-truth era became part of the hegemonic struggles in which power relationships define what is deemed as truthful. Or, to put it another way, "the 'truth'... is not a static set of beliefs, no catechism, but a vital, self-transformative state of being in which the relation between self and belief, self and artifact, self and other, is-we may say-dialectical" (Pinar 1994, p. 73).

I agree as well with Jason Glynos, who argues that it is through the notion of jouissance (enjoyment), in the Lacanian sense, that it may be possible to understand why subjects adhere to these ideological anti-science discourses. Like him, I do not use the terms "fantasy" and "ideology" in opposition to the notion of truth. In Glynos's words (2019), "what makes something appear invested with enjoyment—and in this sense ideological—is not linked to the issue of whether it corresponds or not to a consensus reality so much as how it is caught up in a fantasmatic narrative governed by a logic of desire".

In the terms discussed by Clarke (2012), fantasy offers the possibility to fill our constitutive lack. Fantasy also explains why we lose our jouissance when we separate from the relationship with the (m)other. At the same time, fantasy offers the possibility of recovering that jouissance in order to guarantee a harmonious and full way of existence. Fantasy provides an image of fullness, wholeness, salvation, and harmony; it fills the constitutive void of the subject while placing threats and obstacles to the realization of that fullness on another side - the enemy to be fought as a cause of honor (at the moment, the left-wing or China, for example). In this way, this fantasmatic discourse consists of identifications that will not be deconstructed by rational arguments or the presentation of empirical evidence following a "here is the truth" style. The beatific feeling of fullness produced by such a fantasmatic discourse engenders fundamentalisms and blocks whatever might destabilize such fullness.

Considering the persistence of this fantasmatic discourse, the school and the curriculum will not question anti-science or anti-vaccine discourses in the ambit of post-truth simply through a reaffirmation of school knowledge or the valorization of learning or even through the transmission of "more" scientific content at school. As Prospects readers can see, I am following here a different path from those who try to recreate a new Enlightenment (Pinker 2018).

My aim is to react to the proposal to think about the curriculum in the time of Covid19 , reaffirming the criticisms already made against the learnification of education (Biesta 2015). I start from the understanding that the relationship between curriculum and school must be reaffirmed. However, I do not consider school to be a specific building or place. I argue in defense of school as an institution that creates curriculum through intersubjective relationships in which the subjects are constituted in the relationship itself. The subjects are not pre-existing essences that complement each other. As decentralized subjects marked by a constitutive lack, subjects are always in the process of becoming; they are subjectivations in contextual relationships (Costa and Lopes 2018). In this regard, I consider that during this pandemic, and with specific places of curriculum development closed, we should reactivate this educational sense of school and curriculum and even more strongly oppose the devaluation of the school institution and the devaluation of education.

Some aim, as Paul Auster (2017) does in 4321, to identify different contextual realities that we can draw from the current scenario. However, only literature, the fictive 
institution that extrapolates institutions and in principle allows one to say everything or anything (tout dire) by challenging and suspending the law (Derrida 1992), could make us consider such a multiplicity of curriculum and school contexts. Literature, for Derrida, proposes a form of liberation that calls into question institutionality itself and is related to the notion of modern democracy: greater freedom and infinite possibility of relationships among subjects (Nascimento 2018).

Even so, I consider it increasingly important to reactivate the notions of school and curriculum as linked to radical contextualization. Following a point of convergence between Derrida and Rorty, I maintain that there is no reason to guarantee the possibility of a mode of argument that would have transcended its particular conditions of enunciation (Mouffe 2009). Such a conclusion makes any decision about a curriculum during the time of this pandemic or at any other time a result of radical investment (Lopes 2020). In the sense propagated by Laclau (2004), radical investment is not a priori, not deterministic, not essentialist. Rather, it consists of the attempt to name and represent the unrepresentable: Nothing logically determines or pre-announces normative content, but this content is nevertheless enunciated, and we are invested in its constitution.

This radical investment is somewhat related to the notion of "promise" in Derrida. We-the subjects at schools and producers of theories and curricular proposals-can fulfill the promise that we will "provide opportunities for children to understand what is happening to their parents, to their societies, to them", "address the specificities of our students' situations while reminding them of everyone's global connectedness" (Pinar 2020). However, as with any promise, for "a promise to be possible, it must be haunted or threatened by the possibility of being broken or of being bad" (Derrida 2007, p. 459). This possibility of being bad exists because it is not a program, a calculation that preestablishes a telos. "I promise you will understand", teachers say to their students; "I promise you will be cured", doctors say to their patients. And they must do everything to keep their promises.

Even though we cannot program or pre-establish a future, we will promise and commit to the realization of the project we want. It is because what is to come is not programmable and not pre-established that we can (or should?) promise the other a radical investment in the realization of what we want, always haunted by the possibility of not realizing our project. This is how the curricular promise can be an open invitation to the other, to a translation that is performed only in relation to the other, producing in the context of the school that which is not a mandatory result of a curricular theory.

I maintain that it is up to me, citing many others, to theorize about curriculum and perhaps, in some way, to contribute so that many different curricular proposals are made in different contexts against a reification of the curriculum in order to reaffirm its contextual character.

In this theorizing, I reaffirm that my conception of curriculum theory does not depart from teacher and school practice. On the contrary, it can contribute to a greater approximation. This is done not through the easy way of a theory that is supposed to be accessible to everyone, transparent and evident, without exclusions, but through a theory that conceives practice as inserted in politics. I defend a curriculum theory that does not see itself as constituting the rational norm that guides politics, curriculum content choices, and identity policies in schools. It is a theory that risks theorizing about the unforeseen, the contingent, that de-sediments certainties, reactivates disregarded possibilities, and challenges the claim to define once and for all what curriculum is. Thus, I consider it possible to think of the curriculum - and also the school-as an institution constantly reinvented to face the Covid-19 pandemic in response to the issues proposed in this call. 
In this sense, I do not advocate, in order to fight the harmful results of the pandemic or even to better protect students and their families, that knowledge becomes the centrality of the curriculum. Once again, I question a possible deepening of Michael Young's movement called bringing knowledge back in (Deng 2016), which resonates strongly with the curricular discussions in Brazil and abroad. Instead, as I have done before (Lopes and Borges 2017), I value that knowledge always involves interpretation.

Not interpretation in the hermeneutic sense, as there is no intention to produce a movement of convergence to some interpretative unit. Nor do I speak of interpretation to value polysemy, in its original meaning of pluralized in different forms. I refer to interpretation as textuality, reading, translation, deconstruction: a dispersive, disseminative perspective in which there is no single meaning to be sought or constructed (Bennington 2000).

Authors like Michael Young (2013a, b, 2014, with Muller 2013), who value the centrality of knowledge in the curriculum in its particular relationship with school subjects, seek to guarantee the inheritance of knowledge considered capable of guiding actions, best practices, and performances, and of subsidizing political decisions that are considered adequate and correct because they are based on statements built on solid epistemological ground. This focus on curricular theory attempts to contain the flow of meaning of interpretive processes, and during a pandemic, such control may be considered even more meritorious. After all, the purpose is to save lives through the knowledge necessary to prevent contagion.

I argue that this claim disregards the extent to which any knowledge is subject to interpretation. There is no knowledge to be inherited, such as a collection of stable files, selected by history, without this heritage being supplemented and translated. Interpretation control projects are bound to fail due to the inevitable translations associated with every text, every enunciation. Furthermore, if interpretation is associated with the possibility of invention, its blocking also means blocking possibilities for changing interpretative structures that signify the world. In the constant attempt to change the world through the control of interpretation via knowledge, the possibility of invention of new worlds and events is blocked to an even greater extent.

I do not advocate a pragmatic epistemological conception based on the appeal to consensus or convention, whereby true knowledge would be that which is validated by methods and frameworks accepted in a disciplinary community. This perspective maintains the truth of knowledge attached to what is instituted, to what is included in the system accepted, and is demonstrable by this system and its frameworks (Culler 2008). This view also disregards exclusions, what is outside the consensus and the established discursive hegemony. In Laclau's (1996) terms, it is important to de-sediment what is sedimented, and one way to do that is to understand the universal - an authorized epistemological position, an established discourse - as a particular whose marks of contingency have been erased.

In every process a culture is supposed to transmit, that culture is ready for renewal. In every process in which a novelty is supposed to be instituted, the new is created only by referring to a cultural tradition. Knowledge, tradition, culture, and history are not denied. It is not possible to deny or abandon metaphysics or everything that has been built with it, even if we wanted to. It is inevitable to inherit disciplinary knowledge and structures, as "there is no escape from 'complicity' with tradition (it only provides us with all concepts and vocabularies)" (Bennington 2004, p. 17). This inheritance, however, is read, betrayed, negotiated in processes of translation/deconstruction.

This is a radical investment project that, instead of a supposed relativism and nihilism and abandoning the possibility of producing curricular projects, accentuates the political and is willing to be in a relational and contextual way all the time, deciding and negotiating 
the meanings of the curricular projects in which we invest. In radical investment, there is commitment, action, and responsibility without universal principles or grounds, except for those conceived as particularities that are universalized, always subject to dislocation.

This investment is not just theoretical. Radical investment implies negotiation-not necessarily peaceful — among different particular representations that can be provisionally and precariously universalized. It involves time, power, work, commitment, action, and also affect. As Laclau (2018) argues, it would be a mistake to separate interpretation and signification from the dimension of affect. The intelligibility of something and the investment in this something, argues Laclau, exists only through affect. It is the affect that provides strength to the radical investment in a project.

This is another question to be considered now when we think about curriculum in response to the Covid-19 pandemic. Maintaining curricular activities in any space-time organized for a school activity — online classes, messages, and debates after videos and podcasts on social networks-means creating time to maintain relationships that involve subjectivity, interpretation, and affect.

This can even be a time to produce relationships with our students that favor the deconstruction of the fantasmatic discourses that produce adherence to anti-science and antivaccine positions; to deepen the debate in the school curriculum-in any space-time in which curricula and schools are made-about distrust of medical prescriptions, resistance to mask-wearing, and other efforts to control the spread of the coronavirus in the world.

The curriculum can be one of these space-time of affective relationships, bonds, and subjectivations willing to invest in life, not only the life of each individual but also the lives of the many others with whom we relate in this world.

\section{References}

Auster, P. (2017). 4321. New York, NY: Henry Holt \& Co.

Ball, S. J. (2012). Global education Inc. New York, NY: Routledge.

Bennington, G. (2000). Interrupting Derrida. New York, NY: Routledge.

Bennington, G. (2004). Entrevista com Geoffrey Bennington. In P. C. Duque-Estrada (Ed.), Desconstrução e Ética: Ecos de Jacques Derrida [Deconstruction and ethics: Echoes of Jacques Derrida] (pp. 193234). Rio de Janeiro: PUC-Rio/Loyola.

Biesta, G. (2015). What are schools for? An interview with Gert Biesta on the learnification of school buildings and education. Architecture and Education. https://architectureandeducation.org/2015/05/24/ what-are-schools-for-gert-biesta-on-the-learnification-of-school-buildings-and-education/.

Burki, T. (2020). The online anti-vaccine movement in the age of Covid-19. The Lancet, 2. www.thelancet. com/digital-health.

Clarke, M. (2012). The (absent) politics of neo-liberal education policy. Critical Studies in Education, 53(3), 297-310.

Costa, H. H., \& Lopes, A. (2018). School subject community in times of death of the subject. Policy Futures In Education, 1, 1-17.

Critchley, S. (2014). Memory theatre. London: Fitzcarraldo Ed.

Culler, J. (2008). On deconstruction-Theory and criticism after structuralism (25th anniversary). Ithaca, NY: Cornell University Press.

Deng, Z. (2016). Michael Young, knowledge and curriculum: An international dialogue. Journal of Curriculum Studies, 47(6), 723-732.

Derrida, J. (1992). This strange institution called literature: An interview with Jacques Derrida. In D. Attridge (Ed.), Acts of literature (pp. 33-76). New York, NY: Routledge.

Derrida, J. (2007). A certain impossible possibility of saying the event. Critical Inquiry, 33(2), 441-461.

Farkas, J., \& Schou, J. (2018). Fake news as a floating signifier: Hegemony, antagonism and the politics of falsehood. Javnost-The Public, 25(3), 298-314. https://doi.org/10.1080/13183222.2018.1463047 
Glynos, J. (2019). Two frontiers of discourse theory-Critical populism studies (or, populism studies as vanishing mediator) and critical fantasy studies. Text prepared for circulation and/or presentation to academic colleagues in State University of Rio de Janeiro, Brazil.

Koksal, I. (2020). The rise of online learning. Forbes. https://www.forbes.com/sites/ilkerkoksal/2020/05/02/ the-rise-of-online-learning/?sh=5d2b86f372f3.

Kriedel, C. (2010). Encyclopedia of curriculum studies. Newbury Park, CA: Sage.

Laclau, E. (1996). Emancipations. London: Verso.

Laclau, E. (2004). Glimpsing the future. In S. Critchley \& O. Marchart (Eds.), Laclau: A critical reader (pp. 279-328). London: Routledge.

Laclau, E. (2018). On populist reason. London: Verso.

Lopes, A. C. (2019). Articulações de demandas educativas (im)possibilitadas pelo antagonismo ao "marxismo cultural." Archivos Analíticos De Políticas Educativas, 27, 109-129.

Lopes, A. C. (2020). Investment in curricular normativity in Brazil: A critical-discursive perspective. In J. Chi-Kin Lee \& N. Gough (Eds.), Transnational education and curriculum studies: International perspectives. London: Routledge.

Lopes, A. C. \& Borges, V. (2017). Currículo, conhecimento e interpretação [Curriculum, knowledge and interpretation]. Currículo Sem Fronteiras, 17, 555-573.

Mouffe, C. (2009). Deconstruction and pragmatism. London: Routledge.

Nascimento, E. (2018). A literatura à demanda do outro. Introduction of Essa estranha instituição chamada literatura - uma entrevista com Jacques Derrida [Literature to the demand of the other. Introduction to this strange institution called literature-An interview with Jacques Derrida]. Belo Horizonte, Brazil: UFM Press.

Pinar, W. (1975). The method of “currere”. Paper presented at the annual meeting of the American Research Association, Washington, DC.

Pinar, W. (1994). Autobiography, politics and sexuality: Essays in curriculum theory 1972-1992. New York, NY: Peter Lang.

Pinar, W. (2004). What is curriculum theory? Mahwah, NJ: Laurence Erlbaum Press.

Pinar, W. (2020). Call for Submissions: Special issue of Prospects on curricular responsiveness to Covid-19 crisis. https://www.springer.com/journal/11125/updates/17890172.

Pinker, S. (2018). Enlightenment now: The case for reason, science, humanism, and progress. London: Penguin Books.

Schwartzburg, R. (2019). School's out forever. Slate. https://slate.com/news-and-politics/2019/02/authoritar ians-education-universities-hungary-brazil-populism.html.

Young, M. (2013a). Overcoming the crisis in curriculum theory: A knowledge-based approach. Journal of Curriculum Studies, 45(2), 101-118.

Young, M. (2013b). Powerful knowledge: An analytically useful concept or just a 'sexy sounding term'? Cambridge Journal of Education, 43(2), 131-136.

Young, M. (2014). What is a curriculum and what can it do? The Curriculum Journal, 25(1), 7-13.

Young, M., \& Muller, J. (2013). On the powers of powerful knowledge. Review of Education, 2(1), 229-250.

Publisher's Note Springer Nature remains neutral with regard to jurisdictional claims in published maps and institutional affiliations.

Alice Casimiro Lopes is Full Professor at State University of Rio de Janeiro, Brazil. Her research in curriculum policy is developed in a discursive approach and her projects are financed by Capes, CNPq, and Faperj in Brazil. Her areas of interest are in school subjects, subjectivity, identity, and theory of discourse. She is also the Managing Editor of Transnational Curriculum Inquiry, a journal of the International Association for the Advancement of Curriculum Studies (IAACS), and Director of Graduate Programs, State University of Rio de Janeiro. 